\title{
The present role of in-vitro tests of thyroid function
}

\author{
R. HOFFENBERG
}

From the Department of Medicine (University of Birmingham), Queen Elizabeth Hospital, Birmingham

In recent years a swing has taken place away from tests in vivo of thyroid function, which require the administration of radioactive isotopes, towards tests performed on patients' sera in vitro. This swing has followed the introduction of new, simple, and rapid assay methods, a fresh approach to their interpretation and application, and a simultaneous awareness of the limited discriminatory power of in vivo isotopic methods.

\section{Advantages of Methods in vitro}

The advantages of methods in vitro include the following:

1 The patient need not attend the hospital. While I hesitate to suggest that examination of a patient's serum is a proper substitute for examination of the patient, there are situations in which such a mechanistic approach might be justified. For instance, it is generally agreed that all hyperthyroid patients treated by surgery, radioactive iodine, or long-term administration of antithyroid drugs should be followed up at regular intervals for the rest of their lives. The snowball effect of this accumulation of patients at a thyroid clinic can only lead to less thorough methods of examination, longer waiting times, errors and confusion, and, finally, the patient's disillusionment and non-attendance. It would surely be simpler and less traumatic to ask each patient to attend her general practitioner at, say, annual intervals for clinical assessment and for removal of a blood sample which would be sent to the laboratory for routine thyroid function tests. If either clinical or laboratory assessment suggested thyroid dysfunction the patient would be asked to attend the thyroid clinic.

2 The administration of radioactive isotopes is avoided. The use of short-lived isotopes such as ${ }^{132} \mathrm{I}$ and ${ }^{99 \mathrm{~m}} \mathrm{Tc}$ has made this consideration less cogent, but it is probably undesirable to administer even these to pregnant women, nursing mothers, or infants.

3 Large numbers of samples can be processed. The in- troduction of fully automated techniques for measurement of serum PBI concentrations and of partially automated methods for thyroxine $\left(\mathrm{T}_{4}\right)$ permits the processing of a hundred or more samples per day in a single laboratory. No isotopic test in vivo could compete in terms of throughput. Commercially available kits for $T_{4}$ assay and for serum uptake tests require relatively little technical skill or training.

4 Diagnostic discrimination is improved. In general, tests in vitro offer better discrimination than tests in vivo, an advantage which applies most clearly to the assessment of hyperthyroid patients after treatment or hypothyroid subjects on maintenance thyroxine replacement.

\section{Disadvantages of Methods in vitro}

The disadvantages of methods in vitro include the following:

1 For proper interpretation in the majority of cases a minimum of two tests has been necessary, ie, a measurement of thyroxine level and of unsaturated binding sites which are combined to give a free thyroxine index (FTI). However a single-stage FTI such as the ETR (effective thyroxine ratio) provides similar information from a single test and will be further discussed below.

2 Lack of specificity of the PBI assay: many laboratories still favour PBI measurement on the grounds of the availability of fully automated methods and of cheapness. It is, however, most susceptible to the influence of iodine contamination and false high values are frequently misleading. This can be overcome by measuring thyroxine.

3 Delay in producing results: although individual tests may take only a few hours to perform, tests in vitro are usually done in batches, once or twice a week in most laboratories, so that a delay of several days is customary; with measurement of 'early' thyroid uptake in vivo definitive results can be given within half an hour of referral of the patient.

4 Tests in vitro are not 'dynamic'. Whereas tests 
in vivo may give an indication of the degree and rate of thyroid function, tests in vitro merely express the concentration of hormone in the serum at a particular moment. This disadvantage is probably trivial.

5 Lack of accuracy: with the exception of the PBI assay (by automated techniques) tests in vitro are poorly replicable and coefficients of variation may exceed $20 \%$ in the lower physiological ranges.

\section{Interpretation of Tests in vitro and the Deter- mination of 'Free' $T_{4}$ in Serum}

The major problem with tests in vitro lies in their interpretation, basically because of the influence of the plasma proteins which bind $T_{4}$ and $T_{3}$ (fig 1). An increase in the concentration of serum thyroxinebinding globulin (TBG) with a resultant increase in $T_{4}$ concentration may be of genetical origin but is most commonly due to the effect of oestrogens secreted in pregnancy or contained in oral contraceptive agents; an increase has also been noted in acute intermittent porphyria and in infective hepatitis. A reduced concentration of TBG with low $\mathbf{T}_{4}$ values may also reflect a genetic variation or result from the administration of androgens or anabolic agents, urinary loss of protein in the nephrotic syndrome, or an unexplained effect of



Fig 1 Distribution of ${ }^{125}$ I-T4 in serum protein peaks as demonstrated by two-dimensional crossed immunoelectrophoresis, with subsequent autoradiography. Hormonal radioactivity is noted on thyroxine-binding globulin (TBG), thyroxine-binding prealbumin (TBPA), albumin, $\alpha_{1}$ and $\beta_{1}$-lipoproteins and to a minor degree on other proteins. acute surgical stress or major illness, especially in the $\underline{\bar{\sigma}}$ elderly; certain drugs (diphenylhydantoin or salicy lates) displace $\mathrm{T}_{4}$ from TBG thereby simulating as़ low TBG state.

Where circulating concentrations of $T_{4}$ (and $\left.T_{3}\right) \underline{ }$ are above or below the physiological range because $\frac{\bar{\rho}}{\bar{D}}$ of abnormal concentrations of serum TBG, the $\mathbb{\Omega}_{\Omega}$ subjects are clinically euthyroid and have normalo $\mathrm{T}_{4}$ (and $\mathrm{T}_{3}$ ) secretion rates. This reflects the normal concentration of 'free' (non-protein-bound) hormone? which correlates more precisely with the metabolic $\vec{\omega}$ status of the individual. The serum total $T_{4}$ is ans index of the free $\mathrm{T}_{4}$ concentration only if the binding proteins are present in physiological amounts.

A fundamental requirement, therefore, for proper ${ }_{\omega}^{\infty}$ evaluation of a subject's thyroid status is measure-in ment of the circulating free $T_{4}$ concentration, which ${ }_{0}^{\omega}$ normally comprises only about 0.02 to $0.05 \%$ of theo total $\mathrm{T}_{4}$ or $40-100 \mathrm{pmol} / 1$ serum $(2-5 \mathrm{ng} / 100 \mathrm{ml})$.Direct methods, using equilibrium dialysis or gel 3 filtration, are not suitable for routine use and most $\frac{0}{2}$ laboratories offer as a substitute a 'free thyroxine $\mathcal{\supset}$ index' (FTI) based on an original formulation by $\vec{\theta}$ Clark and Horn (1965). This makes use of measure-v ment of the circulating PBI (or $\mathrm{T}_{4}$ ) concentration and a serum uptake test, the two results in conjunction being taken to reflect the free $T_{4}$ concentration ${ }^{1}$. Howorth and Maclagen (1969) introduced a variant of the serum uptake test using $\mathrm{T}_{4}$ instead of $\mathrm{T}_{3}$ and Goolden, Gartside, and Sanderson (1967) recognized $\stackrel{\varrho}{\rightarrow}$ the non-linear nature of the relationship between the $\overrightarrow{\vec{B}}$ two tests which they attempted to overcome by calculating a free thyroxine factor. Interpretation of these indices is not always straightforward, due:primarily to the effect of other plasma proteins thato bind $\mathrm{T}_{4}$ (fig 1 ) but their validity in the diagnosis of the majority of cases is unquestioned. It should be 3 . stressed that this approach to the assessment of free $T_{4}$ requires two tests: first, a measure of total circulating hormone in the serum (PBI or $\mathrm{T}_{4}$ ) ando second, a measure of the 'unoccupied' hormonebinding sites in serum proteins (serum uptake test). The recently introduced effective thyroxine ratio $2 \stackrel{2}{\sim}$ (ETR) test derives a similar index from a single testos (Thorson, Mincey, McIntosh, and Morrison, 1972); N not all workers have found good reproducibility, N the cost is not significantly less than that of the two standard tests combined, and somewhat greater technical precision is required; good diagnostic: discrimination, however, is achieved. A full evaluation of the ETR test cannot yet be made but it does ${ }_{\square}$ not appear to provide the final answer to the assayo of free $T_{4}$.

${ }^{1}$ See appendix to contribution on Nomenclature by G. K. McGowan

${ }^{2}$ Based on the Mallinckrodt kit. 
Chan and Landon (1972) have recently presented a novel and apparently useful approach to this measurement. Arguing that $T_{4}$ bound to plasma proteins should not be filtered by the kidney, they set out to extract and measure $T_{4}$ in the urine. In a 24-hour sample they found amounts of $T_{4}$ which, by calculation, appeared to reflect the serum free $T_{4}$ (see table). Their results are in agreement with most other published series and excellent diagnostic discrimination has been reported. Closer examination of the excreted iodinated compounds (Burke, 1972; Black, Griffiths, Hoffenberg, and Leatherdale, 1973) raises doubts about the precise interpretation of their urinary findings, but the overall value of the test is highly promising.

A review of in-vitro tests of thyroid function would be incomplete if it failed to discuss the major contributions of serum TSH and $\mathrm{T}_{3}$ measurements, but these items are the subjects of separate papers (for recent reviews see Hall (1972) on TSH and Hoffenberg (1973) on $T_{3}$ ). Urinary $T_{3}$ has been measured by Chan, Besser, Landon, and Ekins (1972) in precisely the same way as $T_{4}$ and seems to provide equally good if not better diagnostic discrimination. Finally, a word should be said about the use of erythrocyte sodium assay (Goolden, Bateman, and Torr, 1971). This test suffers from the defect that it cannot be performed accurately on stored blood, but it distinguishes hyperthyroidism readily and is one of the few tests that directly measures an end-organ response to thyroid hormones. For this reason alone, it deserves a place in the in-vitro thyroid testing armamentarium.

\section{A 'Routine' Approach to Tests of Thyroid Function}

From knowledge of the availability and value of individual thyroid function tests, can a worthwhile 'routine' approach be provided to help to resolve a clinical problem? Or, to look at it from a different angle, what tests should be performed on a serum sample sent to the laboratory for the exclusion of thyroid disease? Figure 2 illustrates an approach developed by Miss H. E. A. Farran (Northwick Park Hospital, Harrow, Middlesex) and myself to cope with the increasingly heavy demands of a busy routine laboratory. As basic tests on all samples we measure the $T_{4}$ concentration (by a modified competitive protein-binding technique) and serum uptake (initially using resin but latterly a Thyopac- $3^{1}$ kit). Consequential tests are based on the results of these two. Where both tests conform with the clinical assessment no problems arise and nothing further needs to be done; in a proportion of cases calculation of a free thyroxine index (or factor) will be needed to quantify the effect of a disturbance of plasma hormone-binding proteins. In a few cases there will be some conflict between the test results and clinical assessment and it is this group that I shall now consider. (One assumes for the sake of discussion that technical or labelling errors have been excluded; in practice, mismatching clinical and laboratory assessments should lead one immediately to reconsider the patient's clinical picture and to repeat the tests.)

It is apparent that four types of conflict may arise, and the steps taken to resolve them are discussed below.

1 THE PATIENT IS CLINICALLY HYPERTHYROID BUT THE TESTS ARE 'EUTHYROID'

Recent work would suggest a diagnosis of $T_{3-}$

${ }^{1}$ Radiochemical Centre, Amersham.

\begin{tabular}{|c|c|c|}
\hline Author & Dialyzable Fraction (\% of total $T_{4}$ ) & $\begin{array}{l}\text { Free } T_{4}(\text { pmoll/l) }(\mathrm{ng} / 100 \mathrm{ml}) \\
\text { Mean } \pm S D(\text { no. })\end{array}$ \\
\hline Anderson (1968) & $0.019 \pm 0.002$ & $\begin{array}{l}34.8 \pm 4.9(42) \\
(1.77 \pm 0.25)\end{array}$ \\
\hline Arango et al (1968) & $0.035 \pm 0.001$ & $\begin{array}{l}49.0 \pm 1.2(316) \\
(2.49 \pm 0.06)\end{array}$ \\
\hline Fang et al (1970) & $0.038 \pm 0.004$ & $\begin{array}{l}49.0 \pm 7.7(20) \\
(2.49 \pm 0.39)\end{array}$ \\
\hline Ingbar et al (1965) & $0.050 \pm 0.009$ & $\begin{array}{l}79.4 \pm 2.14(105) \\
(4.03 \pm 1.08)\end{array}$ \\
\hline Liewendahl et al (1969) & $0.054 \pm 0.008$ & $\begin{array}{l}112.0 \pm 9.5(22) \\
(5.67 \pm 0.47)\end{array}$ \\
\hline Oppenheimer et al (1963) & - & $\begin{array}{l}46 \cdot 3 \pm 5 \cdot 7(22) \\
(2.35 \pm 0 \cdot 29)\end{array}$ \\
\hline Sterling et al (1966) & $0.046 \pm 0.005$ & $\begin{array}{l}83 \cdot 1 \pm 15 \cdot 4(18) \\
(4 \cdot 22 \pm 0 \cdot 77)\end{array}$ \\
\hline Chan et al (1971) & Range calculated from urine $T_{4}$ excretion level & $\begin{array}{l}39 \cdot 0-118 \cdot 0(35) \\
(2 \cdot 0-6 \cdot 0)\end{array}$ \\
\hline
\end{tabular}

Table Variability of free $T_{4}$ measurements by different authors using different techniques and overall comparability of figures derived from the urine method of Chan et al (1972) 


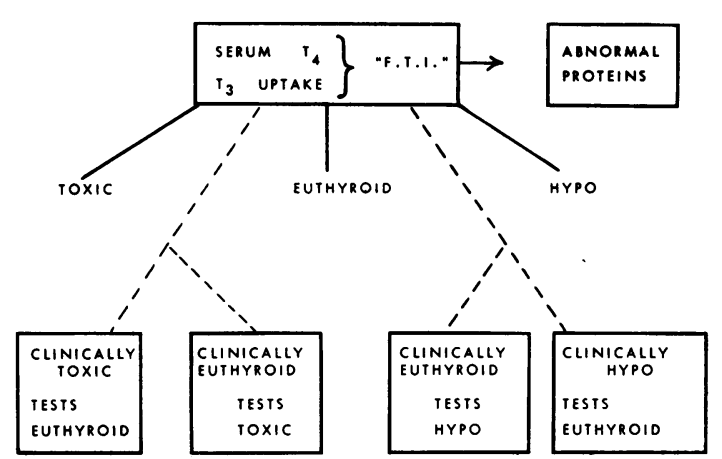

Fig 2 An approach to thyroid function testing, based on the routine measurement of (a) circulating thyroxine concentration, and (b) the availability of binding sites on thyroxine-binding proteins to eradicate problems arising from abnormal concentrations of these proteins. Further investigation (or reconsideration of the diagnosis) follows when tests and clinical assessment fail to conform.

toxicosis (Sterling, Refetoff, and Selenkow, 1970; Hollander, Mitsuma, Nihei, Shenkman, Burday, and Blum, 1972) and estimation of serum (or urine) $T_{3}$ concentration should be undertaken. Thyroidal uptake studies in vivo may help to rule out hyperthyroidism, as uptakes are usually high in $\mathbf{T}_{3}$ toxicosis as well as in the commoner form of the disease. A TRH (thyrotrophin-releasing hormone) test (Hall, Amos, Garry, and Buxton, 1970) may also help to rule out hyperthyroidism since an increase of serum TSH in response to TRH injection is incompatible with this diagnosis. The $\mathbf{T}_{3}$ suppression test (Werner and Spooner, 1955)-a valuable standby for almost 20 years-appears now to have been superseded. If doubt still exists, or if the more sophisticated tests are not available, the clinician may decide to watch the patient for a time or, if the picture warrants it, to give a therapeutic trial of an antithyroid drug.

\section{THE PATIENT IS CliniCALly EUTHYROID, THE TESTS 'TOXIC'}

Clearly the same battery of tests can be applied in this situation, but there is no real need to treat unless the clinical picture changes. A clinical trial of antithyroid drug treatment would be misplaced, as one would be treating the tests and not the patient! Further investigation is probably unnecessary and one would simply watch the patient.

\section{THE PATIENT IS CLINICALLY HYPOTHYROID,} THE TESTS 'EUTHYROID'

The most useful tes: in this instance would be an assay of serum TSH as primary (thyroidal origin) hypothyroidism is probably always associated with a raised serum concentration of this trophic hormone; a low or normal TSH result is not really compatible $\stackrel{0}{+}$ with the diagnosis. In the same way a normal response to TRH is considered to rule out a diagnosis $\frac{\bar{\sigma}}{\overline{0}}$ of hypothyroidism, in which an exaggerated and $\frac{\sigma}{\sigma}$

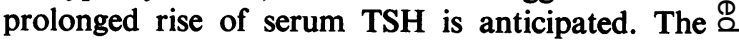
response of the thyroid gland to TSH stimulation क may expose the syndrome of 'low thyroid reserve' $\vec{\circ}$ but, like the $T_{3}$ suppression test, this dynamic test is falling out of favour and is unlikely to remain in $\vec{\omega}$ use for much longer. Simple 'old-fashioned' tests like measurement of the serum cholesterol, an $\overline{0}$ electrocardiograph, or tendon jerk reflex time are of $i_{\infty}$ limited diagnostic value and are most useful in the $\omega$ serial assessment of response to treatment. A N therapeutic trial of thyroxine may be helpful in difficult cases.

4 THE PATIENT IS CLINICALLY EUTHYROID, THE TESTS 'HYPOTHYROID'

Especially after treatment of hyperthyroidism (by surgery, radioactive iodine, or antithyroid drug) $\vec{\theta}$ some apparently euthyroid patients have been $O$ observed to show low circulating PBI or $\mathrm{T}_{4}$ concentrations and serum uptake tests in the hypothyroid range. This is often explained by thyroidal secretion $\bar{\partial}$ of hormone with a high $T_{3} / T_{4}$ ratio, so that serum $\mathrm{T}_{3}$ concentration is normal or high, the patient thus $\stackrel{\mathbb{Q}}{\mathbb{Q}}$ being maintained in a euthyroid state (Sterling, $\underset{\vec{P}}{\vec{P}}$ Brenner, Newman, Odell, and Bellabarba, 1971; 욱 Hoffenberg, 1973). Measurement of serum TSH and, $\frac{\overrightarrow{ }}{2}$ perhaps, its response to TRH might throw further light on the problem, but as long as the patient remains well, fuller investigation or treatment would ? generally be unnecessary.

In presenting this review and an 'approach' to the use and interpretation of in-vitro thyroid function $ᄋ$ tests, I feel I should stress that I do so in a rapidly changing world. What seems reasonable in 1972 to 음 1973 is unlikely to remain so for very long. Radio- $\rightarrow$ immunoassays for $\mathrm{T}_{3}, \mathrm{~T}_{4}$, and TSH should soon be widely available, and simple, reliable tests on serum $N$ and urine might then supersede the more complex studies described here.

\section{References}

Black, E., Griffiths, S., Hoffenberg, R., and Leatherdale, B. (1973). Measurement of urinary thyroxine. Lancet, 1, 152-153.

Burke, C. W., Shakespear, R. A., and Fraser, T. R. (1972). Measurement of thyroxine and triiodothyronine in human urine. Lancet, 2, 1177-1179.

Chan, V., Besser, G. M., Landon, J., and Ekins, R. P. (1972). Urinary tri-iodothyronine excretion as index of thyroid function. $\vec{D}$ Lancet, 2, 253-256.

Chan, V., and Landon, J. (1972). Urinary thyroxine excretion as index of thyroid function. Lancet, 1, 4-6.

Clark, F., and Horn, D. B. (1965). Assessment of thyroid function by the combined use of the serum protein-bound iodine and 
resin uptake of ${ }^{131}$ I-triiodothyronine. J. clin. Endocr., 25, 39-45.

Goolden, A. W. G., Bateman, D., and Torr, S. (1971). Red cell sodium in hyperthyroidism. Brit. med. J., 2, 552-554.

Goolden, A. W. G., Gartside, J. M., and Sanderson, C. (1967). Thyroid status in pregnancy and in women taking oral contraceptives. Lancet, 1, 12-15.

Hall, R. (1972). The immunoassay of thyroid-stimulating hormone and its clinical applications. Clin. Endocr., 1, 115-125.

Hall, R., Amos, J., Garry, R., and Buxton, R. L. (1970). Thyroidstimulating hormone response to synthetic thyrotrophin releasing hormone in man. Brit. med. J., 2, 274-277.

Hoffenberg, R. (1973). Triiodothyronine. Clin. Endocr., 2, 75-87.

Hollander, C. S., Mitsuma, T., Nihei, N., Shenkman, L., Burday, S. Z., and Blum, M. (1972). Clinical and laboratory observations in cases of triiodothyronine toxicosis confirmed by radioimmunoassay. Lancet, 1, 609-611.

Howorth, P. J. N., and Maclagen, N. F. (1969). Clinical application of serum-total-thyroxine estimation, resin uptake, and freethyroxine index. Lancet, 1, 224-228.

Sterling, K., Brenner, M. A., Newman, E. S., Odell, W. D., and Bellabarba, D. (1971). The significance of triiodothyronine (T3) in maintenance of euthyroid status after treatment of hyperthyroidism. J. clin. Endocr., 33, 729-731.

Sterling, K., Refetoff, S., and Selenkow, H. A. (1970). T3 thyrotoxicosis: thyrotoxicosis due to elevated serum triiodothyronine levels. Journal of the American Medical Association, 213, 571-575.

Thorson, S. C., Mincey, E. K., McIntosh, H. W., and Morrison, R. T. (1972). Evaluation of a new in-vitro blood test for determining thyroid status; the effective thyroxine ratio. Brit. med. J., 2, 67-71.

Werner, S. C., and Spooner, M. (1955). A new and simple test for hyperthyroidism employing 1-triiodothyronine and the 24 hour I-131 uptake method. Bull. N.Y. Acad. Med., 31, 137-145.

\section{The February 1975 Issue}

\section{THE FEBRUARY 1975 ISSUE CONTAINS THE FOLLOWING PAPERS}

Computer card morphometry of jejunal biopsies in childhood coeliac disease E. A. MEINHARD, D. G. WADBROOK, AND R. A. RISDON

The predictive value of histometry of thyroid tissue in anticipating hypothyroidism after subtotal thyroidectomy for primary thyrotoxicosis R. J. YOUNG, J. SWANSON BECK, AND W. MICHIE

Observations on the accuracy of point counting including a description of a new graticule BERNARD LENNOX

Observer error in histological assessment of marrow hypocellularity A. MORLEY AND J. BLAKE

Immunopathological changes in rheumatoid arthritis and other joint diseases T. GHOSE, J. F. L. WOODBURY, S. AHMAD, AND BETH STEVENSON

Pneumococcal antigen in lobar pneumonia $P$. TUGWELL AND B. M. GREENWOOD

The distribution of muramidase (lysozyme) in human tissues D. Y. MASON AND C. R. TAYLOR
Normal and pathological serum levels of $\alpha_{2}$-inacroglobulins in men and mice ANITA M. TUNSTALL, J. M. L. MERRIMAN, I. MILNE, AND K. JAMES

The acetyltransferase enzyme method for the assay of serum gentamicin concentrations and a comparison with other methods J. M. BROUGHALL AND D. S. REEVES

Isolations of aerobic sporing bacilli from the tips of indwelling intravascular catheters R. FREEMAN AND B. KING

Strains of Pseudomonas putrefaciens from clinical material B. HOLMES, S. P. LAPAGE, AND H. MALNICK

The measurement of iron-binding capacity in serum and purified transferrin with the aid of chemical affinity chromatography w. N. M. RAMSAY

\section{Technical method}

A simple test for penicillinase in sputum DAVID E. ROBERTS

Letters to the Editor

Book reviews

Copies are still available and may be obtained from the PUBLISHING MANAGER, BRITISH MEDICAL ASSOCIATION, TAVISTOCK SQUARE, LONDON, WC1H 9JR, price $£ 2 \cdot 00$, including postage 